\title{
Utilización de productos de reparación: Adecuación a materiales pétreos y control de su eficacia en el tiempo
}

\author{
Repair products utilization: Suitability to stone \\ materials and effectiveness control through time
}

M.I. SÁNCHEZ DE ROJAS ${ }^{\star}$, N. GARCÍA* ${ }^{\star \star}$ M. FRIAS ${ }^{\star}$

(*) IETCC / CSIC (España)

$\left.{ }^{\star \star \star}\right)$ C.U.M. Universitary Scholl of Monument Conservation. Istituto di Geologia Applicata e Geotecnica. Bari (Italia)

Fecha de recepción: 13-VI-95

Drs. en C. Químicas

\begin{abstract}
RESUMEN
Con el presente estudio se quiere hacer hincapié en la necesidad de realizar ensayos a la hora de seleccionar el tratamiento de restauración a utilizar. Mostrando como los resultados obtenidos sirven para poner de relieve el comportamiento de los productos, aunque conociendo y valorando las limitaciones debidas a situaciones de laboratorio, distintas a las reales en obra.
\end{abstract}

\section{SUMMARY}

With the present study, the necessity of carrying out tests to select the most suitable restoration treatment is remarked. Showing how the results obtained evidence the products behaviour, although knowing and evaluating limitations due to laboratory tests, different to real conditions.

\section{INTRODUCCIÓN}

Los materiales pétreos, utilizados en gran número de monumentos de interés histórico artístico, han sufrido con el transcurso del tiempo alteraciones que han provocado su degradación progresiva. Para evitar, en la medida de lo posible, la destrucción total de estos materiales y con ello la pérdida de gran parte del Patrimonio Histórico, es necesario llevar a cabo trabajos de restauración.

Antes de abordar una labor de reparación en un monumento construido en piedra, hay que desarrollar una serie de estudios previos, que permitan disponer de los datos referentes, no sólo a la propia obra a restaurar, sino también de aquellos derivados de la metodología de conservación planteada.

\section{INTRODUCTION}

Stone materials, largely used in historic-artistic monuments, have undergone alterations through the years that have provoked their progressive decay. To avoid the total destruction of these materials and, consequently the loss of part of the Cultural Heritage, it is necessary to carry out restoring works.

Before starting a repair work in a monument built in stone, a set of previous studies must be developed to have data available referring to the building, and those derived from the conservation methodology planned. 
De este modo, en el estudio del monumento, deben incluirse referencias sobre su historia, las condiciones ambientales que rodean al mismo, el estado actual de la construcción y de los materiales existentes, las causas que han provocado su deterioro arquitectónico, los posibles mecanismos de alteración de la piedra y sus consecuencias. Estos conocimientos permitirán, en la medida de lo posible, frenar el proceso de degradación y evitar daños futuros.

Por otro lado, en la conservación de un monumento, se incluyen tratamientos que abarcan desde procesos de limpieza, sustitución de materiales degradados, y en muchos casos, la utilización de productos de restauración (consolidantes, hidrofugantes) que mejoran las condiciones del material pétreos alterado, "reconstruyendo", en lo posible, sus características iniciales. La incidencia que la incorporación de estas medidas pueden tener en el monumento, hace que sea imprescindible realizar investigaciones que pongan de relieve la eficacia del tratamiento a aplicar, su durabilidad y los efectos secundarios que puedan causar, debido a que su naturaleza suele ser distinta a la del material pétreo original.

El uso de productos de reparación es un tema que representa para el restaurador una gran responsabilidad, ya que del tratamiento seleccionado y del comportamiento piedra-producto depende la subsistencia del propio monumento a restaurar.

Este trabajo se centra en las líneas de actuación a seguir en el estudio y elección de productos de reparación y su adecuación a los materiales pétreos donde van a ser aplicados, indicándose una metodología para controlar su eficacia, bien en el momento de su aplicación como en el tiempo.

\section{SELECCIÓN DE PRODUCTOS DE REPARACIÓN PARA MATERIALES PÉTREOS}

En la selección de productos de conservación hay que considerar que no son admisibles soluciones generales, ya que su comportamiento y evolución con el tiempo dependen, principalmente, del material a tratar y del entorno en el que van a estar situados.

Así, unos productos serán aceptables, según respuesta a los ensayos de caracterización realizados, mientras que otros pueden dar lugar a efectos secundarios que los hagan totalmente rechazables. Según esto, se estima conveniente resolver el problema de la selección del tratamiento adecuado, de acuerdo con las etapas propuestas a continuación:
In this way, the monument study must include references of its history, environmental conditions, the current state of building and present materials, the causes provoking the architectural decay, the possible stone alteration mechanisms and their consequences. This knowledge will provide a decrease in decay processes and the avoidance of future damages.

In other hand, in monuments conservation treatments are included, such as cleaning processes, decayed materials substitution and, in most cases, the use of repair products (consolidants, water-repellent products) that enhance the conditions of altered stone materials reconstructing their initial characteristics. Because of the treatment consequences on the monument, the treatment efficiency must be researched, likewise its durability and secondary effects, due to the incorporated materials different nature with respect to the original ones.

The use of repair products must be responsible because the chosen treatment and the behaviour stone-product will determine the future of the monument.

This paper is centrered in execution lines to follow in the research and election of repair products and their suitability to stone materials, pointing out a methodology to control application effectiveness and durability, in the moment of the application and with time.

\section{REPAIR PRODUCTS SELECTION FOR STONE MATERIALS}

In product selection, general solutions must be avoided because the products behaviour and evolution with time depends on decayed material and environmental conditions.

So, some products will be acceptable according to characterization tests done, while others could produce secondary effects. Next steps must be followed when selecting a suitable treatment: 


\section{I.- Caracterización de los Materiales Pétreos del Monumento}

Los ensayos, con los materiales procedentes del edificio, se basarán en determinaciones que precisen cantidades pequeñas de muestra, de forma que se eviten, en la medida de lo posible, grandes muestreos en el monumento, pero que sin embargo proporcionen datos que sirvan para establecer el tipo o tipos de piedra utilizados en la construcción, así como el estado de alteración de los mismos.

Por otro lado, los ensayos para la caracterización de productos de reparación (1), en su aplicación a materiales pétreos procedentes de edificios históricos, precisan de una gran cantidad de piedra, lo que no es posible conseguir a través de muestreos en la obra a restaurar. Para este fin, es necesario realizar una búsqueda de materiales pétreos semejantes a los existentes en el monumento. Esta búsqueda implica, en primer lugar, la localización de las canteras de las que fueron extraídas las piedras originales; si esto no fuera posible se escogerán materiales procedentes de canteras explotadas en la actualidad, cuya naturaleza petrográfica, mineralógica y química sea la adecuada.

\section{II.- Selección de Materiales de Cantera}

Los materiales seleccionados procederán de canteras que posean el mismo origen geológico que los materiales pétreos del edificio, lo que implica características químicas, mineralógicas y petrográficas semejantes (2).

Una vez conseguidos estos materiales, la elección de las muestras se hace de acuerdo con otras propiedades físicas estudiadas en las piedras del monumento, que influyen directamente en el comportamiento de los tratamientos de restauración, como son los tamaños de poro, granulometría, color, etc.

\section{III.- Caracterización de los Materiales de Cantera}

Una vez seleccionados los materiales de cantera se lleva a cabo una preparación de muestras de acuerdo a las necesidades de los ensayos a realizar. Así, será necesario disponer de cubos, bloques, etc... según las determinaciones programadas.

La metodología seguida en la ejecución de los ensayos utilizados se basa, en principio, en las normas o recomendaciones existentes al respecto. Sin embargo,

\section{Characterization of the Monument Stone Materials}

Tests will be based on determinations requiring small samples amount from the building in order to avoid large sampling in the monument, but obtaining necessary data to established stone kind or kinds used in the building, likewise their alteration state.

In other hand, characterization tests for repair products (1) precise large stone sample and this can not be obtained through sampling. With this objective, it is necessary to search stone materials similar to those present in the monument. This search involves, firstly, locating the quarries from where original materials were extracted; sometimes this is impossible and materials with suitable petrological, mineralogical and chemical nature from present exploited quarries must be chosen.

\section{Quarry Materials Selection}

Selected mateinials must be from stone quarries with the same geological origin than the building stone materials, which implies similar chemical, mineralogical and petrographical characteristics (2).

Once these objectives have been reached, samples choice is done according to other physical properties studied on monument stones, that directly influence the behaviour of restoring treatment, as pore size distribution, granulometry, colour, etc.

\section{Quarry Materials Characterization}

when the quarry materials are selected, sample preparation must be carried out according to the established tests in which cubes, blocks, etc. will be necessary depending on each determination.

T'ests methodology is based on standands and recommendations. However, in many cases, specific methods must be developed for the study of a 
en muchos casos, es necesario desarrollar y poner a punto métodos específicos para el estudio del material pétreo a analizar, de acuerdo con las peculiaridades del mismo (3).

En concreto se trata de determinaciones de:

* Composición química y mineralógica

* Presencia de sales solubles y los correspondientes minerales de neoformación

* Ensayos para establecer la estructura interna del material

Densidad absoluta

Densidad aparente

Porosidad (porosidad accesible al agua, distribución del tamaño de poro)

Permeabilidad al agua y al aire

* Ensayos mecánicos

Resistencia mecánica (flexotracción y compresión)

Dureza (rayado, desgaste, impacto)

* Ensayos de caracterización de propiedades ligadas a la presencia y movimiento de agua

Contenido de humedad

. Absorción de agua y vapor de agua (higroscopicidad)

Curva de saturación y secado

Angulo de contacto

* Cristalización de sales

* Ciclos térmicos

* Ciclos de hielo-deshielo

* Color

\section{IV.- Selección de Productos de Restauración}

Los productos de reparación se seleccionan de acuerdo con el efecto buscado (4). Los tratamientos empleados son principalmente de:

\section{- Consolidación}

Con la consolidación se pretende impedir la desintegración de los materiales pétreos y devolver a los mismos sus propiedades originales de cohesión. Debe evitarse el proporcionar a la piedra deteriorada una resistencia mecánica superior a la original del material, ya que de otra forma se podría ocasionar un deterioro en las piedras sanas situadas en su entorno. particular stone material according to its peculiar properties (3).

Determinations are the following:

* Chemical and mineralogical composition

* Soluble salts presence and the corresponding neoformation minerals

* Tests to establish the internal material structure

. Bulk density

Real density

. Porosity (porosity accessible to water, pore size distribution)

. Water and air permeability

* Mechanical tests (flexural and compressive strength) . Hardness (scratch, impact, erosion)

* Characterization tests related to water presence and mobility

Humidity content

. Water and water vapour absorption (hygroscopicity)

. Saturation and dryness curve

. Contact angle

* Salts crystallization

* Thermal cycles

* Freeze-thaw cycles

* Colour

\section{Repair Products Selection}

Repair products are chosen according to the desired effect (4). The employed treatments are mainly the following:

\section{- Consolidation}

Stone materials decay is impeded with consolidation treatment and the material original cohesion properties are returned. No mechanical strength must be given to the treated stone in order to avoid the decay of sane stones in the environment of the damage one. 


\section{- Hidrofugación}

Para evitar la absorción de agua en la piedra, se emplean productos hidrófugos que actúan superficialmente sobre la misma, protegiéndola.

\section{- Mixtos de Consolidación - Hidrofugación}

\section{COMPORTAMIENTO DE LOS MATERIALES TRATADOS. EFICACIA DE LOS PRODUCTOS SELECCIONADOS}

Al aplicar un cierto producto de restauración es necesario conocer las posibles reacciones que puedan tener lugar entre el material pétreo a restaurar y el tratamiento (5).

También hay que tener en cuenta el poder de penetración del producto en la piedra y las formas de aplicación requeridas; y las posibles dosificaciones producto/disoivente.

Una vez efectuadas estas determinaciones, la piedra tratada se somete a los ensayos señalados en la caracterización del material de cantera, para poder discernir así las variaciones producidas por el producto de restauración.

Sin embargo, según el tipo de tratamiento realizado, se prestará mayor atención a aquellos ensayos que sirvan para poner de manifiesto el efecto buscado con el empleo de dicho producto.

Así, las determinaciones que sirven para establecer la eficacia de un cierto producto consolidante son aquellas que están directamente relacionadas con el comportamiento mecánico resistente de la piedra, es decir:

\section{Profundidad de la penetración \\ Porosidad \\ Resistencia a compresión \\ . Resistencia a flexotracción \\ Dureza \\ Resistencia al desgaste}

De igual forma, los ensayos de caracterización de propiedades ligadas a la presencia y movimiento de agua son los que se utilizan, en especial, para apreciar la eficacia de un hidrofugante:

\footnotetext{
Absorción de agua

Permeabilidad al agua

. Angulo de contacto, consistente en la observación de la forma de una gota de agua sobre una superficie
}

\section{- Water Repellent Treatment}

Water repellent products are employed to avoid water absorption by the stone. They act on the stone surface protecting it.

\section{- Water Repellent-Consolidation joint Treatment}

\section{TREATED MATERIALS BEHAVIOUR. SELECTED PRODUCTS EFFECTIVENESS}

When applicating a repair product, it is important to know the possible reactions between stone materials and the treatment products (5).

Penetration capacity of the product in the stone and methods of application required must be taken into account, likewise the possible dosages product/solvent.

Once these determinations are done, treated stone is submitted to the tests pointed out in the quarry material characterization, in order to know the variations produced by repair product in the stone.

However, according to the type of treatment, more attention will be given to those tests indicating the desired effect with the employment of that product.

So, determinations indicating the effectiveness of a consolidation treatment are those directly related with stone mechanical behaviour, this is:

\section{Penetration depth \\ Porosity \\ Compressive strength \\ Flexural strength \\ Hardness \\ Abrasion resistance}

In a similar manner, test characterizing properties related to water presence and mobility are used, especially, to check out the water repellent effectiveness:

Water absorption

Water permeability

Contact angle, consisting in the observation of a water drop shape on the stone horizontal surface 
horizontal de la piedra, antes y después del tratamiento. Una gota de agua en una superficie plana, que es capaz de absorber, presenta un ángulo de contacto próximo a cero, en una superficie tratada con un hidrofugante, la gota se mantiene más o menos esférica, es decir con un ángulo de contacto gota-superficie superior a 90 grados.

\section{DURABILIDAD DE LOS TRATAMIENTOS APLICADOS}

Los estudios de durabilidad de los tratamientos se hacen de forma que se evalúe el comportamiento de las piedras tratadas con el transcurso del tiempo, en comparación con piedras sin tratar y mantenidas en diferentes condiciones:

*De temperatura y humedad estables y controladas en el laboratorio.

*Ambientales, y por tanto reales, a las que se ve sometido el edificio en cuestión.

*Extremas, obtenidas a través de la realización de ciclos térmicos y con cámaras de simulación de atmósferas contaminantes.

Como se ha mencionado anteriormente, uno de los criterios selectivos de aplicación de un producto es su respuesta ante las condiciones climáticas, factores contaminantes,.. del entorno donde vaya a ser utilizado.

Así, los ensayos realizados en las condiciones ambientales del propio edificio a restaurar son los que proporcionan datos más significativos, pero al tratarse de medidas a tiempo real, precisan de períodos prolongados para la obtención de resultados.

Por este motivo, es necesario llevar a cabo ensayos de envejecimiento acelerado que pongan en evidencia la durabilidad del material, en un plazo de tiempo relativamente corto (6).

También resulta de interés conocer el poder de penetración de los productos en piedras alteradas y en superficies en las que se han efectuado labores de limpieza y saneado. De esta forma se pueden establecer unos criterios de aplicación del producto.

\section{EFECTOS SECUNDARIOS CAUSADOS POR EL TRATAMIENTO}

*Los productos de reparación no tienen que provocar cambios en relación a la piedra original (porosidad, resistencia mecánica, ...), de forma que se eviten tensiones before and after the treatment. A water drop in a flat surface, able to absorb, presents a contact angle close to cero. In a water repellent treated surface, the drop is maintained more or less spherical, with a contact angle drop-surface greater than $90^{\circ}$.

\section{DURABILITY OF THE APPLIED TREATMENT}

Treatment durability studies are done evaluating treated stones behaviour through time in comparison to untreated stones. Different controlled conditions are maintained:

*Stable temperature and humidity, laboratory controlled.

*Environmental and real conditions to which the building is subject

*Extreme conditions, obtained through thermal cycles and with pollutant environment simulation chambers.

As mention former, one of the selective criterium of a product application is its response to climatic conditions, pollutant factors, of the environment where it is going to be used.

Tests done in the building environment are those providing more significative data, but they need large periods of time to obtain valuable results, because they must be real time measurements.

Thus, it is necessary to carry out accelerated aging tests to evidence material durability in a short period of time (6).

It is also of interest to know the products penetration capacity in altered stones and in surfaces with former cleaning treatments. In this way, products application criteria can be established.

\section{TREATMENT SECONDARY EFFECTS}

*Repair products must not provoke changes in the original stone characteristics (porosity, mechanical strength, ...) to avoid internal tension that may damage 
internas que puedan perjudicar aún más el estado actual del material tratado.

* Deben presentar escasa capacidad de absorción de agua, pero permitir la circulación del vapor, ya que si un producto no deja pasar por evaporación el agua existente en el interior del bloque de piedra, se incrementará el deterioro del material.

*El tratamiento empleado tiene que permitir conservar la integridad de la roca durante un período de tiempo de varios años, al cabo de los cuales habrá que plantearse el llevar a cabo una nueva restauración del monumento.

* Además, no han de modificar el color, textura y aspecto de la superficie pétrea, siendo estables a la luz y sin provocar cambios de tonalidad, ni brillos. Así, en un primer control del comportamiento del producto, se tendrá en cuenta este hecho, eliminando todo aquel que pueda modificar la estética del material (7).

\section{EJEMPLOS PRÁCTICOS: TRATAMIENTOS DE RESTAURACIÓN EN MATERIALES PÉTREOS}

En este apartado, se recogen los datos de algunos ensayos realizados en el laboratorio con materiales pétreos, con objeto de comparar los resultados obtenidos, antes y despuès de la aplicación, de productos de conservación. La realización de estos ensayos permite conocer el efecto de los tratamientos sobre dichos materiales pétreos: (a) pueden ser usados como criterios de selección, y (b) para evaluar su eficacia en el momento de la aplicaciòn y en el tiempo.

\section{Medida de Color}

Uno de los principales aspectos a ser tenidos en cuenta en los trabajos de restauración, cuando se emplean tratamientos químicos, es la conservación de la apariencia externa del soporte a restaurar. La superficie de la piedra en contacto directo con los productos de restauración puede sufrir importantes cambios en su color inicial y textura(8).

En muchos casos, las variaciones en el color original pueden ser simplemente detectadas con la observación de las muestras; pero para realizar una observación más cientifica $\mathrm{y}$, ademàs, con objeto de establecer hasta las más pequeñas diferencias producidas, ha sido llevado a cabo la cuantificación de dicha propiedad a través de the treated material.

* Repair products must present small water absorption capacity, but they must let vapour circulation, because if a product does not let water evaporation inside the stone block, material decay will increase.

*Treatment must conserve the rock unaltered during several years, after which, the necessity of a new monument repair must be established.

Besides, other properties of stone material as colour. texture and aspect of the surface must remain stable to light without provoking tone changings or brightness. So, in a first control of the product behaviour, this fact must be taken into account to eliminate products modifying material aesthetics (7).

\section{PRACTICAL EXAMPLES: RESTORATION TREATMENTS IN STONE MATERIALS}

In this point, general data have been collected about some laboratory tests carried out on stone materials in order to compare the results obtained before and after the application of the conservation products. The realization of the tests allowed to know the effect of treatments in stone materials: (a) they can be used as a selection criteria and, (b) to evaluate their effectiveness in the moment of application and with time.

\section{Measurement of Colour}

One of the main aspects to be taken into account in restoration works with the use of chemical treatments, is the conservation of the external appearance of the support. The stone surface directly in contact with the restoration products can undergo important changes in its initial colour and texture (8).

In many cases, the variations in the original colour can be detected simply by looking at the blocks; but for these observations to be scientifically correct and in order to establish so far the smallest differences, an attempt has been made to quantify the degree of this property through the concepts of reflectance and 
los valores de reflectancia y de las coordenadas, cromáticas del material estudiado, obtenidos mediante el uso del espectrofotómetro en las longitudes de onda del espectro visible (380-780 nm). A partir de las medidas tomadas para el material no tratado procedente de la cantera, se puede establecer un intervalo de color que servirá como referencia cuando posteriormente sean aplicados los correspondientes tratamientos elegidos.

Las variaciones de color, en algunos casos, son muy significativas, como se observa en la figura 1.

Inicialmente, una vez establecido el intervalo de color para la arenisca no tratada (arenisca de Villamayor), donde los valores de reflectancia obtenidos varian entre 44 y $56 \%$, se comprueba el efecto debido a la aplicación de una resina epoxi. El uso de este producto hace que el color (valor de reflectancia) "disminuya" considerablemente a lo largo de las longitudes de onda de la zona del visible, de forma que el espectro obtenido para esta muestra se aleja del intervalo de referencia del material original, cuyos valores màs bajos de reflectancia indican un oscurecimiento en el color de la superficie.

La medida del color en materiales pétreos tratados es un elemento a considerar para la posible aplicación o chromatic coordinates given by a spectrophotometer, that provide the visible spectrum of the material under study (380-780nm wavelength). Based on the measurements taken for the untreated stone from the quarry, a colour interval can be established that will serve as a reference when later treatments are carried out on the material.

In some cases, colour variations are more significative, as it is possible to see in Figure 1. Initially, a colour interval was established for an untreated sandstone (Villamayor sandstone) where the values of reflectance were between 44 and $56 \%$ with the use of the epoxy resin. The colour (reflectance value) "decreases" considerably along the visible zone wavelengths. The spectrum obtained for this sample is distanced from the reference range of the original material, with lower values being obtained for reflectance, indicating darker coloured surfaces.

The measurement of colour in treated stones is an element to consider for the possible application of

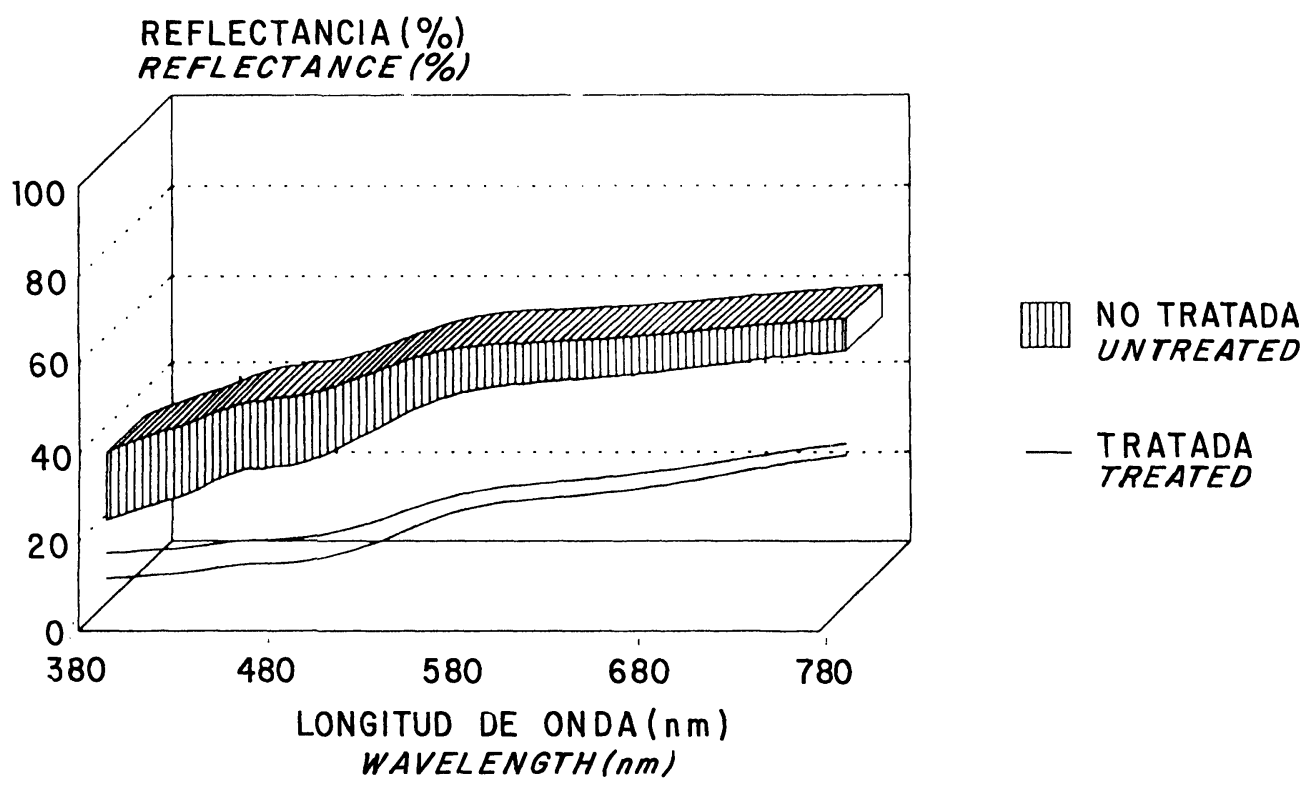

Fig. 1.-Medida de color de la arenisca no tratada y tratada con una resina epoxi. Espectro visible (380-780 nm).

Fig. 1.- Measurement of colour through the reflectance value for untreated sandstone and treated with a epoxi resin. Visible spectrum $(380-780 \mathrm{~nm})$. 
no de los productos de restauración, dependiendo de la variación producida en el intervalo inicial de color de las muestras no tratadas.

\section{Porosidad}

El estudio de la microestructura de una roca, a través del análisis de la porosidad, permite: su descripción, su correspondiente clasificaciòn, el conocer su estado de alteración y el efecto causado por la aplicaciòn de tratamientos químicos (consolidantes y protectores). Los ensayos de porosidad ponen de relieve las variaciones debidas a procesos de alteración o al uso de tratamientos, y permiten establecer diferentes comportamientos entre materiales pétreos de igual o distinta naturaleza (9).

Con la determinación de la distribución de tamaños de poros se determinan los cambios en la porosidad de la piedra con el uso de los tratamientos. Un tratamiento de hidrofugación no tiene porqué afectar a la porosidad de la muestra de forma significativa, ya que tan sólo es aplicado como protector superficial. El descenso de la porosidad en la piedra tratada es más evidente cuando el producto aplicado es un consolidante, debido a que los poros se rellenan parcialmente por la deposición de este tratamiento, disminuyendo el diámetro de los mismos. La diferencia en el valor de la porosidad antes y después del tratamiento no debe ser muy pronunciada, ya que puede suponer una importante alteración del comportamiento original del material pétreo no tratado.

Las figuras $2 \mathrm{a}, 2 \mathrm{~b}$ y $2 \mathrm{c}$ muestran los resultados obtenidos en una caliza antes y después del uso de diferentes productos de conservaciòn: un consolidante (silicato de etilo) y un hidrofugante (polimetil siloxano). En general, no se producen diferencias importantes cuando se comparan la distribución de tamaños de poros, el volumen de intrusión y el diámetro medio de los poros obtenidos.

Con la aplicación del hidrofugante no son detectadas variaciones significativas en los valores iniciales de las propiedades consideradas, mientras que con el uso del silicato de etilo se manifiesta un comportamiento ligeramente diferente al de la caliza no tratada. Los poros de menor tamaño aumentan como consecuencia de la disminución de los diámetros de poros de mayor tamaño.

\section{Comportamiento frente al Agua}

La determinación del comportamiento hídrico de un material pétreo, tratado o no tratado, requiere la realización de los ensayos de absorción-desorción. restoration products, depending on the variation produce in the original colour range of the untreated samples.

\section{Porosity}

The study of the microstructure of a rock through the porosity analysis provides the rock description for its classification and the evaluation of its weathering state and the effect due to the use of chemical treatments (consolidants and protectives). The different tests realized to determine the porosity of stone have shown that especially the porosity characteristics and their changes due to deterioration or use of treatments, enable to distinguish different behaviour in the same stone or to judge the different type of stone (9).

The determination of pore-size distribution permits to record the porosity modification of the stone during the use of treatments. $A$ water repellent treatment is applied only as a surface protector and thus, sample porosity have not to be affected in a significative way. $A$ decrease in the porosity of the treated stone becomes more evident when the applied product is a consolidant, because pores are partially filled by this treatment deposition, decreasing pores diameter. Small differences between porosity values before and after the treatment are desired, because great differences may suppose a significative alteration of the stone material behaviour in comparison to the untreated material.

Higures $2 a, 2 b$ and $2 c$ show the results obtained in limestone before and after the use of different conservation products: a consolidant (ethyl silicate) and a water-repellent (polymethylsiloxane). There are not significative differences either when the pore-size distributions, the total intrusion volume and average pore diameter are compared.

The water-repellent practically do not change the initial values of the considered properties, while the ethyl silicate shows a slightly different behaviour to that of untreated limestone; and it is possible to distinguish a small difference in pore-size distribution, small pores increase in front of the decrease of large pores.

\section{Behaviour linked to the presence of Water}

The determination of the hydric behaviour of an untreated stone material requires the realization of water absorption-desorption tests. The main properties 


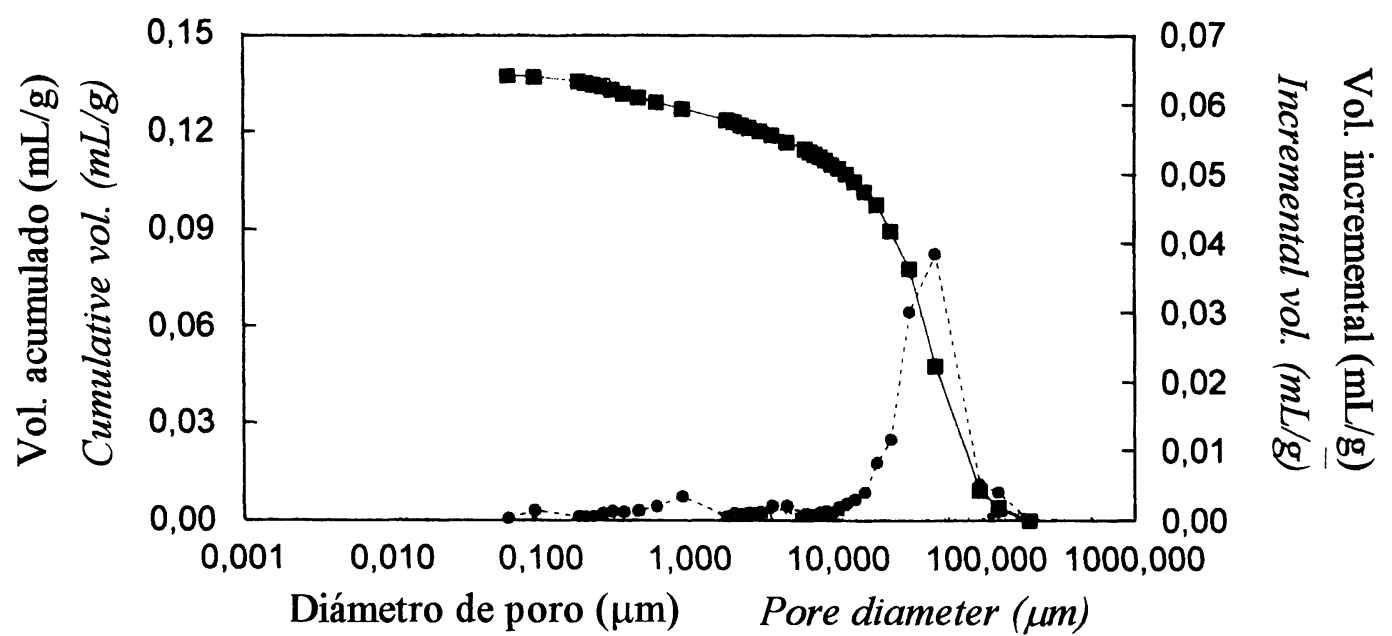

Acumulado - Incremental

Cumulative

Incremental

(a) CALIZA NO TRATADA

(a) UNTREATED LIMESTONE

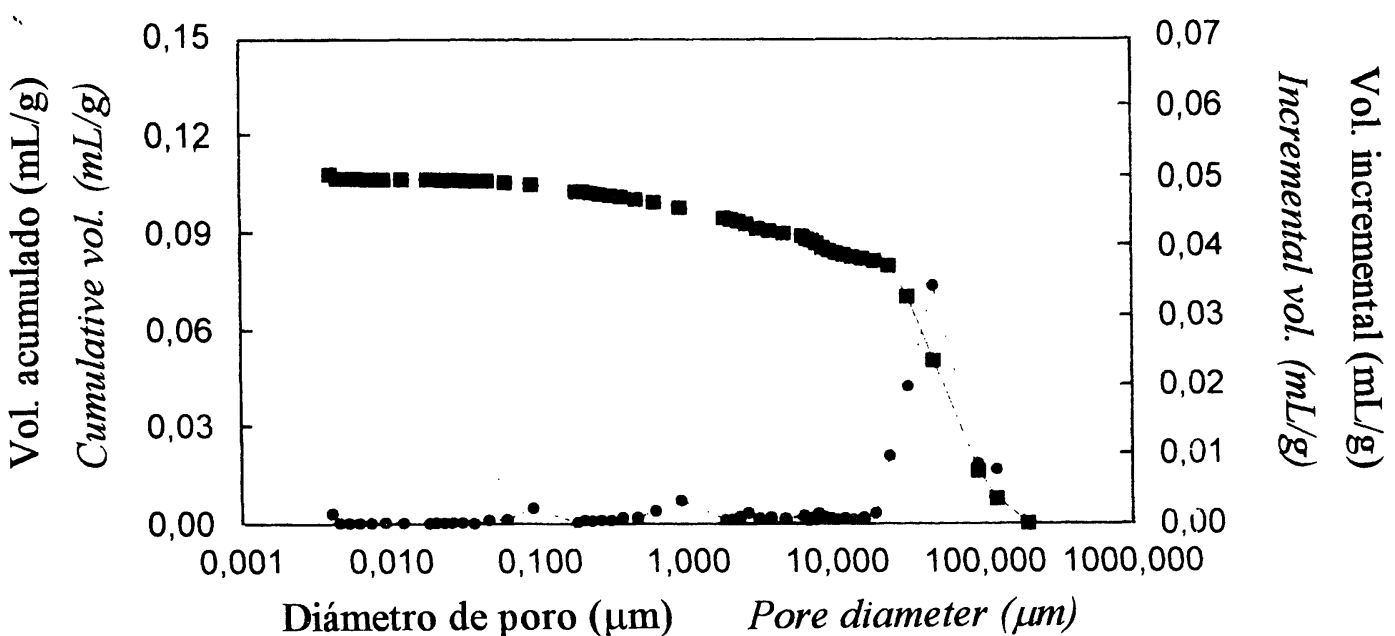

Acumulado - Incremental

Cumulative $\rightarrow$ Incremental

(b) SILICATO DE ETILO

(b) ETHYL SILICATE

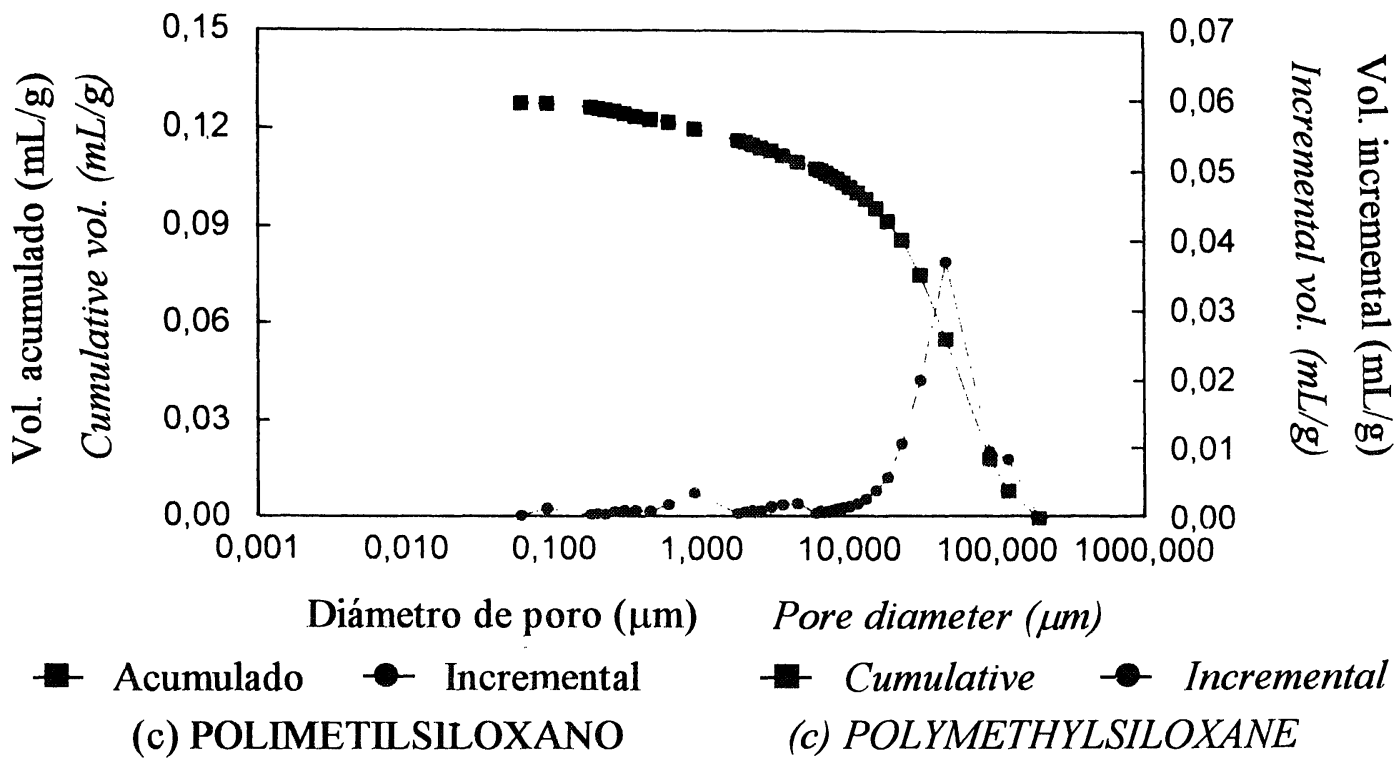

Fig. 2.- Distribución de tamaño de poros de la caliza no tratada (a), tratada con un consolidante (b) y tratada con un hidrofugante (c).

Fig. 2.- Pore-size distributions of untreated limestone (a), treated limestone with a consolidant (b) and treated limestone with a water-repellent (c). 
Dentro de estas propiedades, las que ofrecen resultados más significativos son: la absorción de agua por inmersión total, por capilaridad y la velocidad de evaporación; siendo necesarias para estudiar el efecto de los productos aplicados, sobre todo en aquellos cuya misión es la de proteger a la piedra de la entrada de agua, como es el caso de los hidrofugantes. Estos tratamientos protectores están constituidos, en cuanto a su estructura molecular, por grupos hidrofóbicos que impiden la libre circulación del agua desde el exterior de los bloques, lo que dificultará, además, el desarrollo de todos aquellos procesos químicos ligados a los fenómenos de alteración que normalmente afectan a la piedra y que se ven favorecidos por la presencia de agua.

Las figuras 3, 4 y 5 muestran los resultados de la absorción y evaporación de agua para una caliza no tratada y tratada con dos productos diferentes.

Los resultados del ensayo de absorción de agua por inmersión total, para muestras tratadas con un consolidante y un hidrofugante en comparación a la muestra sin tratamiento, son recogidos en la figura 3 , donde es posible establecer que el comportamiento es prácticamente el mismo para la muestra de caliza no tratada y tratada con un consolidante. Cuando el producto empleado es un hidrofugante, el efecto es bastante más significativo, con una cantidad total de agua absorbida inferior. En el ensayo de absorción de agua por capilaridad (Figura 4) se obtienen resultados semejantes. considered are : water absorption by total immersion, by capillarity and evaporation rate. They are necessary to check the effect of the products whose mission is the protection of the stone from the water entry, as it is the case of water-repellents. This protective treatments are constituted, their molecular structure, by hydrophobic groups that hinder the free circulation of water from the external parts of the stone. Besides, this water absence difficults the chemical processes linked to decay phenomenon, that usually are found in the stones.

Figures 3, 4 and 5 show the results of water absorption and desorption for a treated limestone with two different chemical treatments.

The different trend in the water absorption by total immersion in the untreated limestone and treated limestone with two different products (a consolidant and a water-repellent), is shown in Figure 3, where it is possible to establish that the behaviour of untreated sample and treated with the consolidant is practically the same, but it is different when the test is carried out with a water-repellent, with a total water amount significantly lower. A similar aspect is collected in figure 4 for the water absorption capillarity.

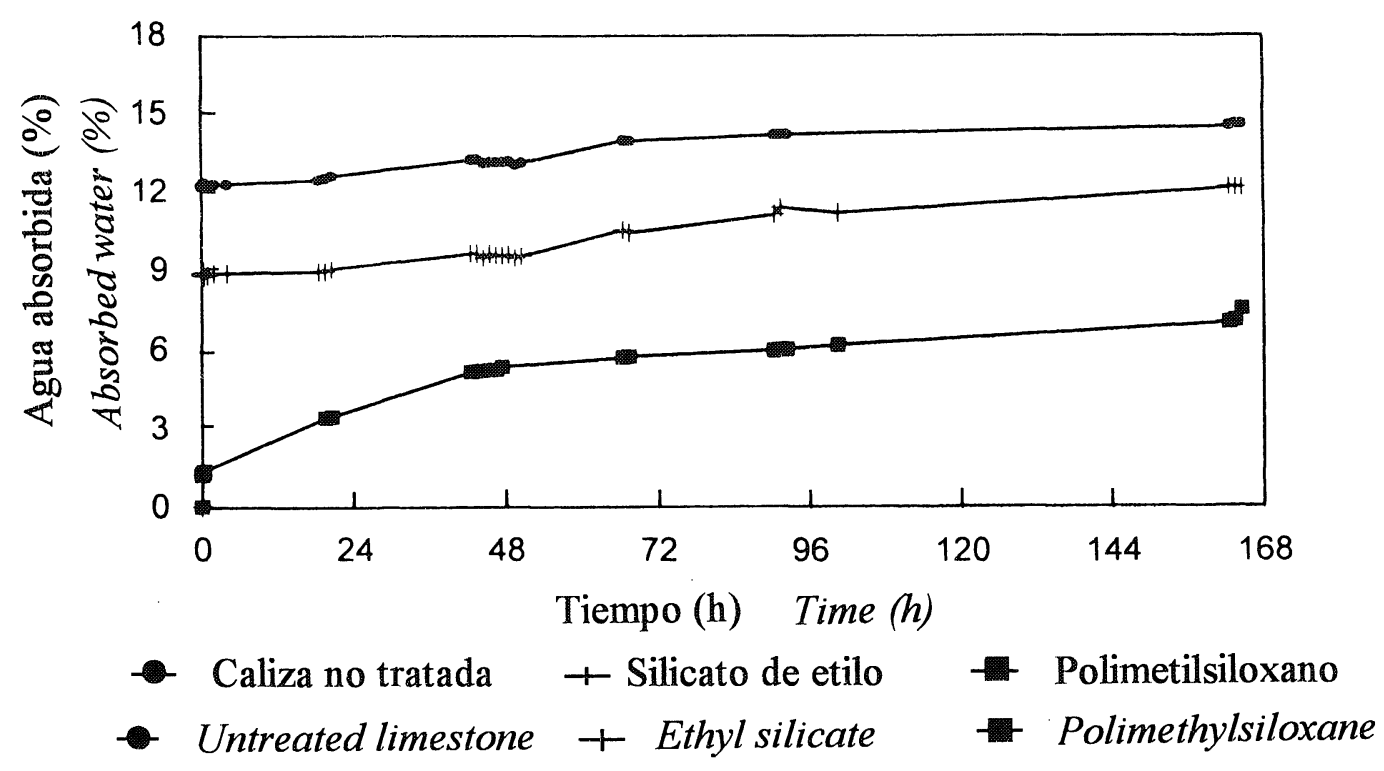

Fig. 3.- Curyas de absorción de agua por inmersión total de la caliza no tratada y tratada con un consolidante (silicato de etilo) y un hidrofugante (polimetilsiloxano).

Fig. 3.- Water absorption by total immersion test in untreated limestone and treated with a consolidant (ethyl silicate) and a water-repellent (polymethylsiloxane). 

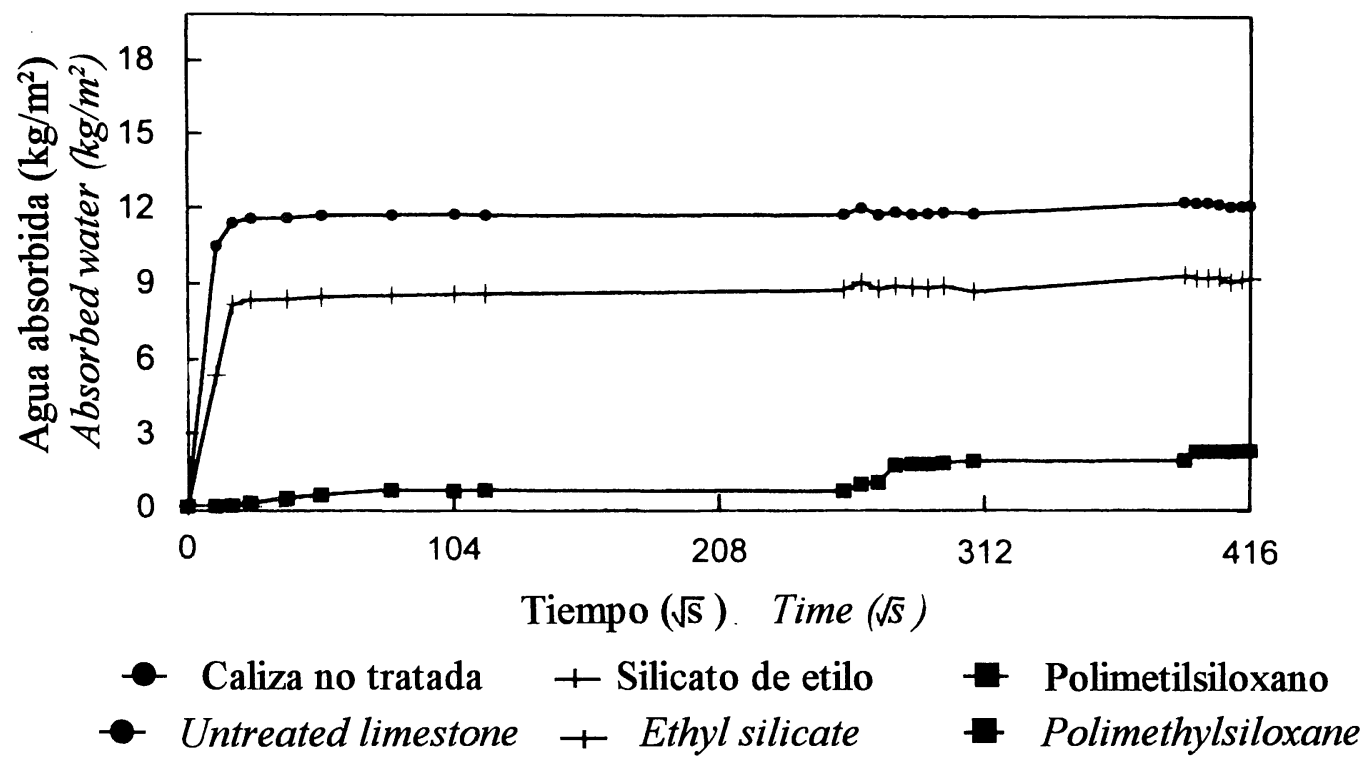

Fig. 4.- Curvas de absorción de agua por capilaridad de la caliza no tratada y tratada con un consolidante (silicato de etilo) y un hidrofugante (polimetilsiloxano).

Fig. 4.- Water absorption by capillarity test in untreated limestone and treated with a consolidant (ethyl silicate) and a water-repellent (polymethylsiloxane).

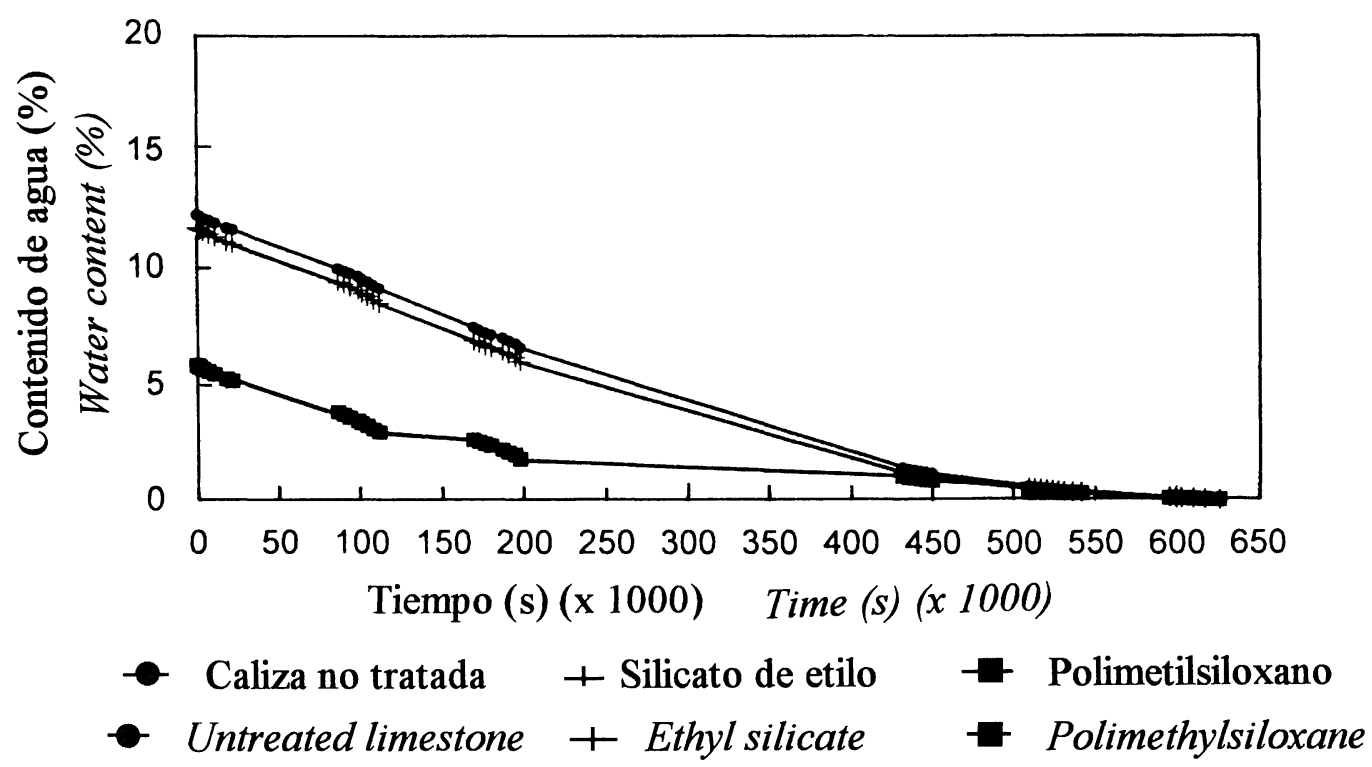

Fig. 5.- Curvas de evaporación de agua de la caliza no tratada y tratada con un consolidante (silicato de etilo) y un hidrofugante (polimetilsiloxano).

Fig. 5.- Water evaporation test in untreated limestone and treated with a consolidant (ethyl silicate) and a water-repellent (polymethylsiloxane).

La acción destructiva que ejerce el agua en los materiales pétreos es bien conocida, aunque debe ser tenido en cuenta que el proceso de eliminación es más perjudicial que el de absorción. Sin embargo, es difícil
It is a difficult attempt to obtain results through the evaporation rate determination since, although it is known the danger of the destructive water action, it is not so much because of absorption, but when this water 
obtener resultados que puedan ser usados como criterio de selección de tratamientos a partir de la curva de evaporación, ya que el fenómeno de evaporación está condicionado a la cantidad de agua absorbida (grado de saturación).

La figura 5 muestra la disminución de la velocidad de evaporación del agua cuando sobre una caliza es aplicado un tratamiento con propiedades hidrófugas, frente al uso de un consolidante o al comportamiento original de la caliza no tratada.

\section{RESULTADOS COMPARATIVOS Y CONSIDERACIONES FINALES. APLICACIÒN DE TRATAMIENTOS CONSERVATIVOS EN DOS MATERIALES PETREOS: ARENISCA Y CALIZA}

Ambos tipos de materiales son muy porosos y, por lo tanto, pueden absorber una importante cantidad de agua; por esta razón, el estudio de las variaciones producidas en la conducta inicial de la arenisca y de la caliza debe de ser considerado como un primer paso para establecer la eficacia o no de los tratamientos aplicados en un trabajo de restauración.

En la tabla I se recogen las variaciones en las propiedades ya descritas, antes y después de la aplicación de cuatro tratamientos, expresadas como tanto por ciento referido al valor inicial correspondiente al material no tratado.

Los valores más bajos indican un comportamiento paralelo al del material no tratado y, teorícamente, teniendo en cuenta el tipo de tratamiento, puede implicar una menor eficacia. De estos resultados, puede establecerse que prácticamente siempre se producen variaciones, aunque en grados diferentes, de acuerdo a los productos empleados. Por un lado, los consolidantes (silicato de etilo y polivinil acetato) muestran un conducta diferente, como era de esperar, de aquella de los hidrofugantes (dimetilpolisiloxano y polimetil siloxano), particularmente en la caliza (9).

De todo esto, puede afirmarse que, en terminos generales, la aplicación de un tratamiento implica una alteración del comportamiento inicial, aunque a veces sea insignificante. Hay que considerar que se aplica una sustancia totalmente ajena a la naturaleza de la roca y, que en mayor o menor grado, actúa como una película que tapiza las paredes de los poros, lo que no sólo influye en el valor de la porosidad, que desciende en todos los casos, si no que también afecta a los valores de todas las demás características. has to be eliminated. It must also be remembered that the amount of absorbed water can affect the value of this evaporation or drying rate.

Figure 5 shows the decrease of the evaporation rate when the treatment with hydrophobic properties is used, in front of untreated limestone or limestone treated with the consolidant. This effect is due to the absorbed water amount (saturation degree) that is also lower than for a consolidant.

\section{COMPARATIVE RESULTS AND FINAL CONSIDERATIONS. APPLICATION OF CONSERVATION TREATMENTS ON TWO DIFFERENT STONE MATERIALS: SANDSTONE AND LIMESTONE.}

\author{
Both types of stone materials are highly porous and \\ therefore they absorb an important amount of water. \\ For this reason, the study of variations in the original \\ physical behaviour of the sandstone and limestone can \\ be considered as a first step in establishing the \\ effectiveness or otherwise of treatments used in \\ conservation work carried out.
}

In the cases of the sandstone and the limestone, table I Icollects the variations found in the properties before and aft the treatment, which are expressed as a percentage with respect to the initial value for the untreated stone materials. Four treatments were selected to show this example.

The lower values obtained indicate a behaviour parallel to that of untreated stone and, theoretically and always taking into account the treatment type, may imply lower effectiveness. From the results, it can only be established that variations occur, although to different degrees, according to the products. Thus, on one hand, the consolidants (ethyl silicate and polyvinil acetate) show a conduct different, as might be expected, from that of the water-repellents (dimethylpoly siloxane and polymethyl siloxane), particularly on limestone (9).

In general terms, the application of a treatment implies an alteration of initial behaviour, even sometimes this alteration is very slight. It must be considered that a foreign substance is applied that, in greater or lesser degree, acts as a film lining the pore walls and thus, influencing not only the porosity values which decreases in all cases, but affecting other characteristics values. 
Variación, en tanto por ciento, de las propiedades físicas de la arenisca (S) y la caliza (L) no tratadas después de la aplicación de los tratamientos seleccionados

(Variation, in percentage, on physical properties of sandstone (S) and limestone (L) after the selected treatments application)

\begin{tabular}{|c|c|c|c|c|c|c|c|c|}
\hline \multirow{2}{*}{$\begin{array}{l}\text { Propiedades } \\
\text { físicas } \\
\text { (Physical } \\
\text { properties) }\end{array}$} & \multicolumn{2}{|c|}{$\begin{array}{l}\text { Polivinil } \\
\text { acetato } \\
\text { (Polyvinyl } \\
\text { acetate) } \\
\end{array}$} & \multicolumn{2}{|c|}{$\begin{array}{c}\text { Silicato de } \\
\text { etilo } \\
\text { (Ethyl } \\
\text { silicate } \\
\end{array}$} & \multicolumn{2}{|c|}{$\begin{array}{c}\text { Dimetil- } \\
\text { siloxano } \\
\text { (Dimethylpoli- } \\
\text { siloxane) } \\
\end{array}$} & \multicolumn{2}{|c|}{$\begin{array}{l}\text { Polimetil- } \\
\text { siloxano } \\
\text { (Polymethyl- } \\
\text { siloxane) }\end{array}$} \\
\hline & $S$ & L & $S$ & L & $S$ & L & $S$ & $\mathrm{~L}$ \\
\hline $\begin{array}{c}\text { Porosidad } \\
\text { accesib. Agua(\%) } \\
\text { (Porosity acc. } \\
\text { To water(\%)) }\end{array}$ & 2,5 & 1,6 & 7,6 & 19,3 & 7,8 & 10,0 & 4,9 & 7,1 \\
\hline $\begin{array}{c}\text { Densidad aparente } \\
\left(\mathrm{g} / \mathrm{cm}^{3}\right) \\
(B u / k \text { density } \\
\left.\left(\mathrm{g} / \mathrm{cm}^{3}\right)\right) \\
\end{array}$ & $-1,1$ & 0,0 & $-1,7$ & $-7,7$ & $-0,6$ & $-1,1$ & $-0,6$ & $-0,5$ \\
\hline $\begin{array}{c}\text { Densidad real } \\
\left(\mathrm{g} / \mathrm{cm}^{3}\right) \\
(R e a / \text { density } \\
\left.\left(\mathrm{g} / \mathrm{cm}^{3}\right)\right) \\
\end{array}$ & 0,4 & 0,7 & 0,8 & 1,1 & 3,4 & 3,4 & 1,5 & 2,6 \\
\hline $\begin{array}{l}\text { Coef. Absorción } \\
\text { por inmersión } \\
\text { total (\%) } \\
\text { Water absor. Coef. } \\
\text { Total immers. (\%)/ }\end{array}$ & 20,3 & 3,3 & 21,8 & 19,3 & 25,4 & 59,5 & 42,1 & 64,3 \\
\hline $\begin{array}{l}\text { Coef. Absorción } \\
\text { capilar }\left(\mathrm{g} / \mathrm{cm}^{2} \mathrm{~s}^{1 / 2}\right) \\
\text { (Water absor. Coef. } \\
\text { capillarity } \\
\left.\left(\mathrm{g} / \mathrm{xm}^{2} \mathrm{~s}^{1 / 2}\right)\right)\end{array}$ & 78,5 & 80,4 & 38,5 & 97,1 & 83,1 & 96,1 & 90,8 & 98,6 \\
\hline
\end{tabular}

\section{BIBLIOGRAFÍA}

(1) DE ANGELIS D'OSSAT, G.: "Guide to methodical study of monuments and causes of their deterioration". ICCROM, Rome (1972).

(2) GARCIA, N.; SÁNCHEZ DE ROJAS, M.I.; LUXÁN, M.P. Y FRÍAS, M.: Proc. 2nd Int. Symp. The Conservation of Monuments in Mediterranean Basin, pp 463-467, Geneve (1991).

(3) RILEM, Comm. Stones, Group 25 PEM.: "Recommended tests to measure the deterioration of stone and to asses the effectiveness of treatment method". Matèriaux et Constructions, Vol. 13, N. 75, pp 175-253, (1980).

(4) WEBER, H. Y BOYER, D.W.: APT Bulletin, Vol. XVII, N.2 (1985). 
(5) SÁNCHEZ DE ROJAS, M.I. Y GARCÍA, N.: XIII CEMCO, Seminario S3 (1995).

(6) HEIMAN, J.L.: Proc. Vth Int. Cong. on Deterioratiopn and Conservation of Stone, Torum (1988).

(7) GARCÍA, N.; SÁNCHEZ DE ROJAS, M.I.; FRÍAS, M.: BIA, N. 164, pp 44-50 (1993).

(8) GARCÍA, N.; SÁNCHEZ DE ROJAS, M.I.; FRÍAS, M.: BIA, N. 167, pp 83-96 (1993).

(9) GARCÍA, N.; SÁNCHEZ DE ROJAS, M.I.; FRÍAS, M.: Proc. Int. Coll. on Methods of Evaluating Products for the Conservation of Porous Building materials in Monuments, Rome, pp 147-162 (1995).

\section{publicación del IETCC/CSIC}

\section{JORNADAS SOBRE CEMENTO ALUMINOSO}

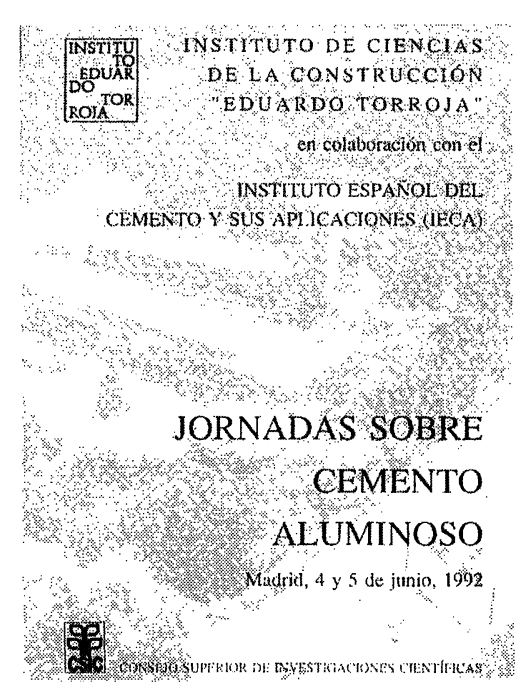

El Instituto Eduardo Torroja publica integramente -en colaboración con el Instituto Español del Cemento y sus Aplicaciones (IECA) - las "Jornadas sobre cemento aluminoso", celebradas en junio de 1992.

Se recogen las conferencias dictadas por destacados especialistas en la materia, así como las intervenciones suscitadas en los coloquios y en la interesante Mesa Redonda, tras la cual se clausuraron las Jornadas.

El tratamiento dado al tema del hormigón y cemento aluminoso por los intervinientes abarca tanto aspectos rigurosos científico-técnicos como de indole práctica, abordando temas de corrosión de armaduras, durabilidad, protección y reparación de los elementos constructivos con daños causados por diversas motivaciones ampliamente expuestas.

Este libro será, sin duda, una eficaz ayuda tanto para el científico o el técnico estudioso de esta materia, como para aquellos profesionales interesados en un tema de tanta importancia y actualidad como es el relacionado con los hormigones de cemento aluminoso.

Un volumen de $15,5 \times 22,5 \mathrm{~cm}, 186$ págs., con figuras de línea, gráficos, tablas, etc.
} 